\title{
The performance and egg quality characteristics of layers fed diets containing graded levels
} of Garcinia kola seed meal

Esiegwu, A.C., Emenalom, O.O., Enyenihi, G. E., Okoli, I.C. and Udedibie*, A.B.I.

Department of Animal Science and Technology, Federal University of Technology

Owerri, Nigeria.

*Corresponding author: e-mail: abiu_futo@yahoo.com

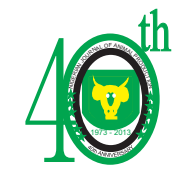

\begin{abstract}
Effects of dietary Garcinia kola meal (bitter kola) on the performance and egg quality characteristics of laying hens were investigated. Four layers diets were made such that diet $\mathrm{T}_{0}$ (control) contained no Garcinia kola meal while diets $\mathrm{T}_{2.5}, \mathrm{~T}_{5.0}$ and $\mathrm{T}_{7.5}$ contained $2.5 \%, 5.0 \%$ and $7.5 \%$ Garcinia kola meal, respectively. Each diet was fed to a group of 30 laying hens at 30 weeks of laying life for 84 days, using completely randomized design (CRD). Each group was further sub-divided into three replicates of 10 hens each. The layers on $T_{2.5}$ and $T_{5.0}$ diets added significantly $(\mathrm{P}<0.05)$ less body weight than those on $\mathrm{T}_{0}$ and $\mathrm{T}_{7.5}$ diets. There were no significant differences in their feed intake $(\mathrm{P}>0.05) . \mathrm{T}_{2.5}$ significantly $(\mathrm{P}<0.05)$ depressed hen-day egg production but enhanced egg weight. Feed conversion ratio ( $\mathrm{g}$ feed/ $\mathrm{g}$ egg) was not affected by the treatments $(P>0.05)$. Egg quality indices (egg shape index, egg specific gravity, Haugh unit, egg shell thickness, albumen index and yolk index) were not affected by the treatments $(\mathrm{P}>$ $0.05)$. Egg shell index was significantly $(\mathrm{P}<0.05)$ enhanced by Garcinia kola meal. At $2.5 \%$ level, it significantly enhanced percent albumin and reduced percent yolk $(\mathrm{P}<0.05)$. Cost of egg production ( $\$ / \mathrm{kg}$ eggs) was adversely increased as the level of Garcinia kola meal increased.
\end{abstract}

Key words: Egg production, egg quality, Garcinia kola, laying hens.

\section{Introduction}

There is no doubt that the costs of providing feed and drugs in livestock and poultry industry in Nigeria are steadily increasing. These costs affect the final consumers of the products. South-eastern agro-ecological zone of Nigeria is highly endowed with plants possessing nutritional and medicinal properties. It has therefore become necessary to investigate such plants for possibilities of incorporating their leaves or seeds in livestock and poultry feeds to serve as feed ingredients and/or prophylactic agents. Earlier studies at our station have shown that leaves form Alchornia cordifolio (Udedibie and Opara, 1998) and Azadirchta indica (Esonu et al., 2005) could be of value in poultry diets.

Garcinia kola, Heckel, commonly called bitter kola is an indigenous medicinal tree belonging to the family, Guttiferae. It is highly valued because of its medicinal properties (Hertog et al., 1993). The seeds are chewed as an aphrodisiac or used to cure cough, dysentery or chest cold in herbal medicine (Irvine, 1961). Phytochemical studies have shown that the seed's constituents include biflavoids, xanthones and benzophenones. The seeds are believed to have antimicrobial, anti-inflammatory, anti-bacterial and anti-viral properties (Akoachere et al., 2002), and very low in protein and high in carbohydrates (Ibekwe et al. 2007). It could therefor be used as feed additive in view of its medicinal properties or feed ingredient as source of carbohydrates

Information on the nutritive value of Garcinia kola in poultry diets is sketchy. Esiegwu and Udedibie (2009) reported that 
Egg quality characteristics of layers fed diets containing graded levels of Garcinia kola seed meal

Table 1: Ingredient composition of the experimental layers diets

\begin{tabular}{|c|c|c|c|c|}
\hline \multirow[b]{2}{*}{ Ingredients $(\%)$} & \multicolumn{3}{|c|}{ Experimental Diets } & \multirow[b]{2}{*}{$\mathrm{T}_{7.5}$} \\
\hline & $\mathrm{T}_{0}$ & $\mathrm{~T}_{2.5}$ & $\mathrm{~T}_{5.0}$ & \\
\hline Maize & 48.00 & 45.50 & 43.00 & 40.50 \\
\hline Bitter kola & 0.00 & 2.50 & 5.00 & 7.50 \\
\hline Soybean meal (48\% CP) & 15.00 & 15.00 & 15.00 & 15.00 \\
\hline Fishmeal $(65 \% \mathrm{CP})$ & 2.00 & 2.00 & 2.00 & 2.00 \\
\hline Blood meal & 3.00 & 3.00 & 3.00 & 3.00 \\
\hline Wheat offal & 14.00 & 14.00 & 14.00 & 14.00 \\
\hline Palm kernel cake & 7.00 & 7.00 & 7.00 & 7.00 \\
\hline Bone meal & 10.00 & 10.00 & 10.00 & 10.00 \\
\hline Salt & 0.25 & 0.25 & 0.25 & 0.25 \\
\hline Tm/Vit. premix * & 0.25 & 0.25 & 0.25 & 0.25 \\
\hline L-lysine & 0.25 & 0.25 & 0.25 & 0.25 \\
\hline L-methionine & 0.25 & 0.25 & 0.25 & 0.25 \\
\hline Total & 100.00 & 100.00 & 100.00 & 100.00 \\
\hline \multicolumn{5}{|c|}{ Calculated nutrient composition ( $\%$ of DM) } \\
\hline $\mathrm{CP}$ & 17.95 & 17.80 & 17.64 & 17.48 \\
\hline $\mathrm{CF}$ & 4.52 & 4.96 & 5.41 & 5.85 \\
\hline $\mathrm{EE}$ & 3.85 & 3.97 & 4.10 & 4.24 \\
\hline Ash & 4.47 & 3.23 & 3.22 & 3.22 \\
\hline NFE & 69.21 & 70.04 & 69.63 & 69.21 \\
\hline $\mathrm{Ca}$ & 3.75 & 3.75 & 3.75 & 3.75 \\
\hline $\mathrm{P}$ & 2.10 & 2.17 & 2.16 & 2.16 \\
\hline Lysine & 1.18 & 1.18 & 1.17 & 1.16 \\
\hline Methionine & 0.57 & 0.57 & 0.56 & 0.56 \\
\hline ME (Mcal/kg) & 2.62 & 2.61 & 2.60 & 2.58 \\
\hline
\end{tabular}

broilers placed on Garcinia kola seed meal diets produced heavier body weight and superior feed conversion ratio at $2.5 \%$ dietary level.

The study herein reported was therefore designed to determine the effects of graded levels of Garcinia kola seed meal on the performance of laying hens.

\section{Materials and methods}

The Garcinia kola seeds used in this study were bought from Omuma market in Oru East Local Government Area of Imo State,
Nigeria. The seeds were cut into small pieces and sun-dried until they became crispy. They were then milled in a hammer mill with $2 \mathrm{~mm}$ sieve to produce Garcinia kola seed meal. Samples were subjected to proximate and mineral analyses according to AOAC (1990).

\section{Experimental diets}

Four layers diets were compounded, incorporating Garcinia kola seed meal at $0 \%, 2.5 \%, 5.0 \%$ and $7.5 \%$ inclusion levels, respectively, partly replacing maize in the control diet. The diets were thus designated 
as $T_{0}, T_{2.55} T_{5.0}$ and $T_{7.5}$, respectively, with $T_{0}$ serving as the control. The ingredient and nutrient compositions of the diets are shown in Table 1.

\section{Experimental birds and designs}

One hundred and twenty (120) laying hens of Hyline strain at 30 weeks of laying life were randomly divided into four groups of 30 layers each and each group randomly assigned to one of the four treatment diets in a completely randomized design (CRD). Each group was further sub-divided into three replicates of 10 layers each and each replicate housed in a deep litter compartment measuring $1.5 \mathrm{~m} \times 2 \mathrm{~m}$. Feed and water were provided ad libitum.

\section{Data collection and analysis}

The birds were weighed at the beginning of and end of the feeding trial to obtain their body weight changes. Records on daily feed intake were taken by weighing the feed given and the left-over the following day. Feed conversion ratio was recorded as daily feed intake per daily egg weights ( $\mathrm{g}$ feed/ $\mathrm{g}$ egg). The following egg parameters were determined: hen-day egg production, egg weight, shell weight, shell-thickness, yolk index, albumen index and Haugh unit. Egg yolk index were determined according to Funk (1948), albumen index according to Heiman and Carver (1936) and Haugh unit using the simplified formula of Haugh (1937) as cited by Asuquo et al. (1992).

Three eggs were collected weekly from each replicate and analysed for egg quality indices while a crate of eggs from each replicate was weighed weekly to obtain average egg weights. Data collected were subjected to analysis of variance (Snedecor and Cochran, 1978). Where analysis of variance indicated significant treatment effects, means were compared using Duncan's New Multiple Range Test (DNMRT) as outlined by Obi (1990).

\section{Results and discussion Proximate and mineral composition}

The proximate and mineral compositions of Garcinia kola used for the experiment are shown in Table 2. With exception of crude fibre, which was $20.51 \%$, other values (crude protein, ether extract and ash) were in agreement with the values obtained by Ibekwe (2000). The values for $\mathrm{Mn}, \mathrm{Mg}, \mathrm{Ca}$ and $\mathrm{K}$ were close to the values of 2.01 $\mathrm{mg} / 100 \mathrm{~g}$ for $\mathrm{Mn}, 0.42 \mathrm{mg} / 100 \mathrm{~g}$ for $\mathrm{Mg}$, $0.80 \mathrm{mg} / 100 \mathrm{~g}$ for $\mathrm{Ca}$ and $2.50 \mathrm{mg} / 100 \mathrm{~g}$ for $\mathrm{K}$ respectively, reported by Okwu (2005). The value for $\mathrm{Zn}(0.003 \mathrm{mg} / \mathrm{g})$ tended to disagree with the value of $2.03 \mathrm{mg} / 100 \mathrm{~g}$ and $2.23 \mathrm{mg} / \mathrm{kg}$ reported by Okwu (2005) and Odebunmi et al. (2009), respectively, possibly because of the differences in locations of the studies as soil and other climatic conductions can affect nutrient composition of plants. The variability in the values is, however, not too wide.

\section{Performance of the experimental laying} hens

The performance of the experimental laying hens is presented in Table 3. There were no significant differences $(\mathrm{P}>0.05)$ in feed intake and feed conversion ratio among the treatments. The layers on $\mathrm{T}_{2.5}$ and $\mathrm{T}_{5.0}$ added significantly $(\mathrm{P}<0.05)$ less body weight than those on $\mathrm{T}_{0}$ and $\mathrm{T}_{7.5}$ diets. Similar trend in body weight had earlier been reported by Esiegwu and Udedibie (2009) on broilers fed similar levels of Garcinia kola seed meal. Uko et al. (2001) also reported that water extract from Garcinia kola fed to rats had depressive effect on feed intake. There were no treatment effects on hen-day egg production $(\mathrm{P}>0.05)$ at inclusion levels of 5.0 and $7.5 \%$. The reason for the significantly $(\mathrm{P}<0.05)$ poor performance of the group on $2.5 \%$ inclusion level cannot be immediately established. The results tended to contradict the findings of Adedeji 
Egg quality characteristics of layers fed diets containing graded levels of Garcinia kola seed meal

Table 2: Proximate and mineral composition of Garcinia kola seeds (DM basis)

\begin{tabular}{lr}
\hline Proximate composition (\% of DM) & \\
\hline Dry matter, \% & 92.70 \\
Crude protein & 2.64 \\
Crude fibre & 20.51 \\
Ether extract & 9.47 \\
Ash & 1.07 \\
Nitrogen free extract & 57.54 \\
Macro elements (mg/g) & \\
Magnesium & 0.28 \\
Calcium & 0.25 \\
Potassium & 1.61 \\
Phosphorus & 0.057 \\
Sodium & 0.282 \\
Chlorine & 0.400 \\
Sulphur & 0.073 \\
Micro elements (mg/g) & \\
Fe & 0.02 \\
Zinc & 0.003 \\
Cupper & 0.05 \\
Manganese & 0.012 \\
\hline
\end{tabular}

et al. (2008) that Garcinia kola tended to significantly $(\mathrm{P}<0.05)$ enhance hen-day egg production. This could be as a result of the differences in ingredient composition of the diets used in the two trials.

The eggs of the Garcinia kola groups were heavier than the control with $2.5 \%$ and $5.0 \%$ inclusion levels having significant treatment effect $(\mathrm{P}<0.05)$. Adedeji et al. (2008) observed no significant differences in egg weight.

Economics of production showed that feed cost increased as the dietary level of Garcinia kola meal increased due to the high cost of the test material. This invariably resulted in very high egg production cost as the dietary levels of the meal increased.

\section{Egg quality indices}

There were no treatment effects $(\mathrm{P}>0.05)$ on egg shape index, egg shell index, egg shell weight, egg specific gravity, Haugh unit, egg shell thickness, albumen index and yolk index. $\mathrm{T}_{2.5}$ had significantly $(\mathrm{P}<$ 0.05 ) heavier percent albumen than the other treatments while the control had significantly $(\mathrm{P}<0.05)$ heavier percent yolk. Harms and Hussein (1993) reported that eggs containing a large proportion of thick white albumen are regarded as being of high quality. This implies that Garcinia kola produces good quality eggs. The findings tended to indicate that Garcinia kola meal had no negative effects on the quality of the eggs produced.

\section{Conclusion}

The results of the study have shown that Garcinia kola, nutritionally speaking, is mainly a carbohydrate concentrate. The results also showed that the meal at dietary levels of $2.5-7.5 \%$ slightly reduced egg production but enhanced egg weights of laying hens. It did not adversely affect egg quality. However, at its current market price, it cannot be recommended as feed 
Table 3: $\quad$ Performance indices of laying hens fed graded levels of Garcinia kola

\begin{tabular}{|c|c|c|c|c|c|}
\hline \multirow[b]{2}{*}{ Parameters } & \multicolumn{3}{|c|}{ Experimental Diets } & \multirow[b]{2}{*}{$\mathrm{T}_{7.5}$} & \multirow[b]{2}{*}{ SEM } \\
\hline & $\mathrm{T}_{\mathrm{o}}$ & $\mathrm{T}_{2.5}$ & $\mathrm{~T}_{5.0}$ & & \\
\hline Av. initial body weight (kg) & 1540.1 & 1565.7 & 1503.3 & 1527.2 & 10.21 \\
\hline Av. final body weight $(\mathrm{kg})$ & 1751.1 & 1680.0 & 1630.6 & 1711.2 & 19.38 \\
\hline Av. body weight changes ( $g$ ) & $211.00^{\mathrm{a}}$ & $123.33^{\mathrm{b}}$ & $130.67^{\mathrm{b}}$ & $190.00^{\mathrm{a}}$ & 12.87 \\
\hline Av. daily feed intake (g) & 133.02 & 132.38 & 135.84 & 136.74 & 0.78 \\
\hline Hen-day egg production $(\%)$ & $67.43^{\mathrm{a}}$ & $54.83^{\mathrm{b}}$ & $63.73^{\mathrm{a}}$ & $59.00^{\mathrm{ab}}$ & 3.25 \\
\hline Egg weight $(g)$ & $58.54^{\mathrm{b}}$ & $0.27^{\mathrm{a}}$ & $60.78^{\mathrm{a}}$ & $59.55^{\mathrm{ab}}$ & 0.36 \\
\hline Feed conversion ratio & & & & & \\
\hline ( $g$ feed/g egg) & 2.27 & 2.20 & 2.23 & 2.30 & 0.02 \\
\hline Cost of feed ( $\mathbb{N} / \mathrm{kg}$ feed) & 82.61 & 109.26 & 135.91 & 162.56 & - \\
\hline Cost of production ( $\mathbb{A} / \mathrm{kg}$ egg) & 187.52 & 240.37 & 303.08 & 373.89 & \\
\hline Mortality & 0.00 & 0.00 & 0.00 & 0.00 & - \\
\hline
\end{tabular}

Table 4: $\quad$ Egg quality indices of the experimental laying hens

\begin{tabular}{|c|c|c|c|c|c|}
\hline \multirow[b]{2}{*}{ Parameters } & \multicolumn{4}{|c|}{ Expeirmental Diets } & \multirow[b]{2}{*}{ SEM } \\
\hline & $\overline{\mathrm{T}_{0}}$ & $\mathrm{~T}_{2.5}$ & $\mathrm{~T}_{5.0}$ & $\overline{T_{7.5}}$ & \\
\hline \multicolumn{6}{|l|}{ External egg quality } \\
\hline Egg weight (g) & $60.09^{\mathrm{b}}$ & $64.80^{\mathrm{a}}$ & $64.86^{\mathrm{a}}$ & $63.77^{\mathrm{a}}$ & 0.85 \\
\hline Egg shape index & 0.74 & 0.77 & 0.75 & 0.74 & 0.01 \\
\hline \multicolumn{6}{|l|}{ Internal egg quality } \\
\hline$\overline{\text { Haugh unit (HU) }}$ & 53.60 & 52.60 & 50.81 & 51.15 & 0.53 \\
\hline Albumen index & 0.16 & 0.18 & 0.16 & 0.18 & 0.03 \\
\hline Yolk index & 0.40 & 0.41 & 0.35 & 0.37 & 0.07 \\
\hline Percent albumen & $59.04^{\mathrm{b}}$ & $73.42^{\mathrm{a}}$ & $58.61^{\mathrm{b}}$ & $62.18^{\mathrm{b}}$ & 2.04 \\
\hline Percent yolk & $26.17^{\mathrm{a}}$ & $20.77^{\mathrm{c}}$ & $23.18^{\mathrm{bc}}$ & $24.83^{\mathrm{ab}}$ & 0.70 \\
\hline Shell weight (g) & 4.80 & 5.05 & 5.99 & 5.59 & 0.25 \\
\hline Egg shell index & $10.98^{\mathrm{b}}$ & $10.97^{\mathrm{b}}$ & $13.03^{\mathrm{a}}$ & $12.12^{\mathrm{ab}}$ & 0.55 \\
\hline Egg shell thickness (mm) & 0.34 & 0.30 & 0.31 & 0.31 & 0.02 \\
\hline Egg specific gravity & 1.08 & 1.07 & 1.08 & 1.08 & 0.00 \\
\hline
\end{tabular}

${ }^{a b c}$ Means within the same row with different superscripts are significantly different $(\mathrm{P}<0.05)$

ingredient in laying diets in view of its negative effect on feed cost and cost of egg production.

\section{References}

Adedeji, O.S., Farinu, G.O., Olayemi, T.B., A meen, S.A. and Babatunde, G. M. 2008 . Performance and egg quality parameters of laying hens fed different dietary inclusion levels of bitter kola (Garcinia kola). Res. J. Poult. Sci., (4): 75 - 77.

Akoachere, J.F., Ndip, R.N., Chenwi, E.B., Ndip, L.M., Njock T.E. and Anong, D.N. 2002. Antibacterial effect of Zingiber officinale and Garcinia kola on respiratory tract pathogens. East Afr. Med. J., 79 (11): 588 - 592.

AOAC. 1990. Association of Official Analytical Chemists, Official Methods of Analysis, $13^{\text {th }}$ Edition, 
Egg quality characteristics of layers fed diets containing graded levels of Garcinia kola seed meal

Washington D.C. USA.

Asuquo, B.O., Okon, B. and Ekong A.A. 1992. Quality parameters of Isa Brown and Nigerian local chicken eggs. Nig. J. Anim. Prod., 19:1-5.

Esiegwu, A.C. and Udedibie, A.B.I. 2009. Growth performance of and anti-microbial activities in broilers fed supplementary bitter kola (Garcinia kola). Animal Production Research Advances, 5(1): 20 - 24.

Esonu, B. O., Emenalom, O.O., Udedibie, A.B.I., Anyanwu, G.A., Madu, U. and Inyang, A.O. 2005. Evaluation of neem (Azadirchta indica) leaf meal on performance, carcass characteristics and egg quality of laying hens. Intl. J. Agric. Rural Devt., (6): 208-212.

Funk, E.M. 1948. The relation of the yolk index determination in the natural portion of the yolk as determined by separating the yolk from the albumen. Poultry Sci., 27: 361.

Irvine, F. R. 1961. Woody Plants of Ghana with Special Reference to Their Uses. Oxford University press, London.

Harms, R.H. and Hussein, S.M. 1993. Variations in yolk albumen ratio in the eggs from commercial flocks. $J$. App. Poult. Res., 2(2): 166-170.

Haugh, R.R. 1937. The Haugh unit for measuring quality of egg. U.S. Poultry Magazine, 43: 552 - 555.

Heiman, V. and Carver, T. S. 1936. The albumen index as a physical measurement of egg quality. Poultry Sci., 15:141 - 148.

Hertog. M.G.I., Fejkeen, E.J.M., Hokman, C.H. and Katan, A. 1993. Dietary antioxidant flavonoids and risk of coronary heart disease, de zutphen elderly study. Lancet, 342: 2007-1011.

Obi, I.U. 1990. Statistical Methods of Detecting Differences Between Treatment Means. $2^{\text {nd }}$ Edn., Snap Press, Enugu, Nigeria.

Odebunmi, E. O., Oluwaniyi, O. O., Awolola, G. V. and Adediji, O. D. 2009. Proximate and nutritional composition of kola nut (Cola nitida), bitter cola (Garcinia kola) and alligator papper (afromomum melegueta). Afri. J. of Biotechnology, 8(2): 308-310S

Okwu, D. E. 2005. Phytochemical, vitamin and mineral contents of two Nigerian medicinial plant. Intl. J. of Molecular Medicine and Adv. Sci., 1(4): $375-381$.

Snedecor, G.W. and Cochran, W.E. 1978. Staistical Methods, $6^{\text {th }}$ ed., lowa State Univ. Press, Ames-lowa.

Udedibie, A.B.I. and Opara, C.C. 1998. Response of growing broilers and laying hens to the dietary inclusion of leaf meal from Alchornia cordifolia. Anim. Fd. Sci. Tech., 71: 157-164.

Uko, O.J., Usman, A. and Ataja, A. M. 2001. Some biological activities of Garcinia kola in growing rats. Vet. Arhiv., 71:287-297. 